\title{
ЯЗЫКОЗНАНИЕ
}

UDC 811.512 .1

\section{Is $<$ Voluntative+-(i)di $>$ in Cypriot Turkish contact-induced? References to Common Turkic}

\author{
G. S. Sakhatova \\ Georg-August-Universität Göttingen, \\ 14, Heinrich-Düker-Weg, Göttingen, 37073, Germany
}

For citation: Sakhatova G. S. Is <Voluntative+-(i)di $>$ in Cypriot Turkish contact-induced? References to Common Turkic. Vestnik of Saint Petersburg University. Asian and African Studies, 2019, vol. 11, issue 2, pp. 152-172. https://doi.org/10.21638/spbu13.2019.202

The present paper purports to reflect the mood/modality formation in Cypriot Turkish focusing on the morphologic formation $<$ Voluntative $+-(\mathrm{i}) \mathrm{di}>$ which consists of the markers -(y)AyIm 1. Person singular or -sIn 3. Person singular and of the copula -(i)di. In previous research on Cypriot Turkish syntactical properties this compound is considered to be a Cypriot Greek influenced phenomenon and therefore, specified as having a non-turkic origin. This generally accepted position in the research on Cypriot Turkish needs a scrutiny. I argue therefore, against its non-turkic nature and analyse this morphologic compound referring to the fact that the formation $<\mathrm{Vol}+$-(i)di $>$ is already attested at early development stages of Turkic and is well evidenced in older Turkic sources. My argument is further based on pioneering studies in this field by Starostov, Kononov as well as on other studies, entries in different grammars and dictionaries, and, further, on the fact that similar morphologic formations occur also in (colloquial) Turkish and Turkmen. The methodological principal of the study that makes it possible to read Cypriot Turkish $<$ Vol+-(i)di $>$ constructions is founded on the approach 'from meaning to form' employed by Bondarko (1984, St. Petersburg School of Functional Grammar). The present study contributes to on-going investigations, which concern themselves with both grammatical markers and lexical units in the mood/modality concepts in Turkic languages in general and, in particular, continues to research category interactions in Turkic, such as <volitional mood+tense copula(?)/nominal split(?)> that seems to be a paradox if viewed from the angle of their incompatibility.

Keywords: Cypriot Turkish, Turkic languages, Voluntanive, mood and modality in Turkic languages, copula -idi, Turkmen, Turkish.

() Санкт-Петербургский государственный университет, 2019 


\section{Introduction}

The grammatical formation 'Voluntative first person singular -(y)AyIn/-(y)AyIm and -sIn third person singular' hereafter referred to as $<\mathrm{Vol}+$-(i)di $>$ is actively used in Cypriot Turkish [henceforth CT], one of the spoken languages in Cyprus. Previous studies on syntactical features of Cypriot Turkish viewed this morphologic compound as having a non-turkic origin assuming that this paradigm might be a contact-induced phenomenon resulting from language contacts between Cypriot Greek [hereafter abbreviated to CG] and CT. The non-turkic origin of $<\mathrm{Vol}+-(\mathrm{i}) \mathrm{di}>$ is a generally accepted view of previous scholars, representing their guidelines in studies on both syntactical and CT mood properties. One of the reasons for believing in its the non-turkic origin is a conclusion resulting from differences in expressing modality between CT and Standard Turkish [hereafter cited as ST], since for the ST grammar the formation $<\mathrm{Vol}+$-(i)di $>$ demonstrates a kind of incompatibility in categories. While a CT speaker uses $<\mathrm{Vol}+$-(i)di $>$ to express modality such as possibility, wish etc., a ST speaker achieves the same purposes by other means, such as nominalised verbs, as can be seen in the following examples:

CT (1) ister gideyimdi/gitsindi eve 's(h)e wants (that) I (would/should) go home' ST (2) eve gitmemi/gitmesini istiyor

CT (3) sanmam öyle yapsindī? I I don't think she (would/should) act like that?' ST (4) öyle yapacağını düşünmüyorum

The present paper discusses the compound marker $<\mathrm{Vol+}+(\mathrm{i}) \mathrm{di}>$ in $\mathrm{CT}$ with references to common Turkic. I argue therefore, that $<\mathrm{Vol}+$-(i)di $>$ is not a result of the CT-CG language contacts and favour a different view referring to its Turkic nature. My argument is based both on studies by Starostov [1], Kononov [2] and entries in different grammars and dictionaries, as well as on the fact that similar grammar compounds occur also in the (colloquial) Turkish or Turkmen. Further, the issue about the origin of the marker -(i)di in $<$ Vol+-(i)di $>$ remains a controversial one. A few scholars have thoroughly dealt with the origin of -(i)di in combinations with the voluntative suffixes and have seen it either as a tense copula or as a remnant of some adverbs. I will introduce their viewpoints and hypotheses also in the context of the issue category interaction <voluntative mood + tense copula (?) or nominal split(?)>. This overview primarily provides a key finding that this interaction in CT is in no way a paradox and has existed in Turkic long before.

The structure of the paper is the following. Section 2 addresses the state of the art on the CT. The narrative is focused on studies that describe the subjunctive mood and its formation in CT, drawing comparisons between ST or CG. Section 3 contains references from earlier researches as well as entries from grammars and dictionaries on the complex marker $<$ Vol+-(i)di $>$. A solid Turkic (typology) portrait of the compound in question is thereby created. Section 4 provides a short outline of the approach 'from meaning to form' employed by Bondarko [3]. This methodological principle supports the present analysis in reading $\mathrm{CT}<\mathrm{Vol}+-$ (i)di $>$ constructions, first of all from the speaker's perspective and not from the listener's perspective, as is quite often the case particularly in descriptions of traditional grammar. In the present paper however, I make no distinction between the terms $<$ language, dialect or regional patois $>$ and apply all of these terms as synonymous. 
Numerous examples from my own CT language database which contains references to both the city-koine [a variety of Turkish spoken in Nicosia] and village vernaculars ${ }^{1}$ show the semantic diversity in $<$ Vol+-(i)di $>$ utterances. Those are analysed in Section 5, according to the established turcological practice and basics of the Leipzig Glossing Rules, which give information about the meanings and grammatical features of word units. Morphemes in the examples from CT will be segmented, and the morphologic compound $<$ Vol+-(i) $\mathrm{di}>$ at the corresponding positions additionally complemented by abbreviations for semantic values, such as VOLneces, which stands for Voluntative necessity. Section 6 illustrates further, related morphological markers for equivalent semantics found in Turkmen examples, which were collected during own fieldwork in Turkmenistan. The origin of the marker - $\mathrm{dA}$ in Turkmen utterances with similar semantics, like in the case of origin of -(i)di, will be discussed here, too. To conclude, in Section 7, I will summarise and interpret the findings in order to accurately characterize incompatibility, or otherwise, of the phenomenon 'voluntative mood + tense copula (?)/nominal split(?)' in CT with common Turkic perspectives, arguing that the paradigm in discussion was already attested in Old and Middle Turkic texts as well as in other Turkic languages, such as (colloquial) Turkish or Turkmen.

\section{Previous studies on syntactical properties in Cypriot Turkish}

In studies on syntactical properties of CT [6-13] the mood formations are, either briefly mentioned or compared between ST or CG. The most common observation in the papers however, is that the syntactic properties in CT such as formation of the subjunctive mood differs from those in Standard Turkish.

However, Demir $[7 ; 8]$ comments that the main features distinguishing CT varieties from mainland Turkish Anatolian dialects appear in the area of syntax. Kappler [13, p.205] conforms this opinion and points out further, “...the most striking syntactic patterns copied from Greek (and perhaps partly also from English) occur in embedded clauses, especially in object clauses, relative clauses, and "subjunctive" clauses." Further, Demir $[8 ; 14]$ touches on constructions shaped by imperative-optative markers, structuring right branching subjunctives with the verb isde 'to want' as amaç cümleleri [objective/ purpose sentences]. Gulle [11], as well as Abdurrazak [6], while focusing on CT syntactic particularities, compared certain utterances with their counterparts in Standard Turkish and Cypriot Greek.

According to Abdurrazak [6, p. 239] $<\mathrm{Vol}+-(\mathrm{i}) \mathrm{di}>$ utterances are subjunctive constructions. Describing aspect/tense and modality issues, the author notes in the context of expressing eventual modality however, that the lines between modal uses of the past tense markers in CT are not as sharp as is in Old Anatolian Turkish or in Standard Turkish. The author concludes finally that their formation is one of the many problematic issues of the CT grammar: "[...] however, perhaps the most prominent modal structures standing out in the tense / aspect / modality system of TDC [Turkish dialect of Cyprus] are subjunctive forms. This is a situation alien to the Turkic finite system and definitely is a result of lan-

${ }^{1}$ My own CT language database was collected during my residences in Cyprus in 2014 and 2016. Informants providing examples of CT were aged between 50 and 70, residing in Nicosia, Pyla, Lepta, Potamia/ Dereliköy, and Karpaz. For studies dealing with apprehensive, necessity and evidentiality in Cypriot Turkish as well as in different Turkic/Oghuz languages such as Turkmen or Azerbaijani see $[4 ; 5]$. 
guage contact." This point of view is entirely based on comparison between CT, a spoken Turkic variety, and ST, as between a written and a standard language, respectively.

The non-conformance of morphological marking of the optative or subjunctive moods in both languages, CT and ST, therefore, led previous scholars to the assumption that the subjunctive mood formation in CT shows a contact-induced property, as influenced by Cypriot Greek.

Furthermore, Kappler and Tsiplakou [12, p. 141-142] likewise term $<$ Vol+-idi $>$ constructions 'the subjunctive-optative paradigms', comparing with examples from Standard Turkish as well as other Turkic varieties such as Gagauz, Azeri or Rhodian Turkish². Moreover, in that field the authors suggest a local development of contact-induced issues, a kind of the 'common Cypriot subjunctive', which exists neither in Standard Turkish nor in Standard Greek. Kappler\&Tsiplakou [12, p. 149] additionally, posit the questions as to the origin of -idi and its syntactical function:

"(1) Why does CT use an intensifier with a non-fictive or contra-factive subjunctive;

(2) what does the intensifier 'intensify'; as well as

(3) can intensifier be treated as a copy of the CG copula despite the fact that the CG copula does not have 'an intensifying' function?"

In further papers $[8$, p. 169-170; 9; 21] moreover, alongside the CG influence, an effect of English on CT mood formations is also presumed, likewise resulting from morphologic distinctions between CT and ST.

Summing up the examination of the studies on mood phenomena in CT the following aspects can be identified. First, closely related to this topic is the issue of language contacts between Turkish and Greek varieties spoken in Cyprus. Second, the CT utterances with $<\mathrm{Vol}+$-(i)di $>$ as subjunctives are compared to possible equivalents in the ST or/and CG in detail and listed as atypical for Turkic verbal system, since the ST speaker's morphological and lexical means to express subjunctive semantics is completely different to that of the CT speaker. Third, all studies mentioned above provide statistical data based on a rich collection of morphologic-syntactic properties found in Cypriot Turkish ${ }^{3}$. However, it needs to be mentioned that the comparative approach relevant to the languages in question is very scarce and limited only to the Standard Turkish mood/modality concepts without paying attention either to mood/modality concepts in different Turkic languages, or to diachronic factors, such as the history of Turkic.

What all previous studies have in common, - regardless of whether they have or have not established a link between the syntactic and mood features found in Cypriot Turkish and those found in Cypriot Greek, - is that they all concluded that the language contacts between Turkish and Greek in Cyprus had a decisive influence on the Cypriot Turkish syntax.

${ }^{2}$ Grammarians usually title the paradigm also 'optative'; Lewis [15] terms this formation 'subjunctive'; Johanson [16], and Adamović [17] 'voluntative'; Aslan-Demir [18] as gönüllük kipi; Ščerbak [19] - 'optativ, voluntativ, kohortativ'. See Grunina [20] on the history of Turkic optative as exemplified by Oghuz languages.

For a systematic approach in indicating moods and modality in common Turkic the reader is referred also to Rentzsch [30], Guzev [24], Johanson [57].

3 The authors such as Gulle, Kappler\&Tsiplakou set also numerous examples from CG. 


\section{State of research on $<$ Vol+-(i)di $>$ in Turkic}

Conclusion of Abdurrazak [6, p.239] as to subjunctive forms in CT being alien to the Turkic finite system, and therefore having to be seen as a definite result of the CT-CG language contacts, mirrors a generally accepted belief in Cypriot Turkish research. This observation is however, highly doubtful, since both an examination of available studies on $<$ Vol+-(i)di> as well as its descriptions in dictionaries are contradictory to this view. In addition, occurrence of the morphologic compound in the Old and Middle Turkic texts as well as in other Turkic languages demands that this belief be further scrutinized. Source determinations provide us with an objective basis also for resolving of the so-called paradox in CT <voluntative mood + tense copula(?)/nominal split(?)>. Going a little forward, we should summarize the following outcome gleaned from the review of previous studies:

(1) The complex marker $<$ Vol+-(i)di $>$, which the CT speaker still applies in order to express different modality meanings, is deeply rooted in the history of Turkic. In Old and Middle Turkic texts the combination of $<\mathrm{Vol}+$-(i)di $>$ is already attested ${ }^{4}$.

(2) There are $<\mathrm{Vol}+-(\mathrm{i}) \mathrm{di}>$ constructions in (colloquial) Turkish as one of the rarer paradigms, or similar constructions in (colloquial) Turkmen.

(3) The origin of the second signifier -(i)di in $<$ Vol+-(i)di $>$ is in fact, unclear and remains a controversial subject. When shortly summarised at first, two main assumptions present themselves: -(i)di could be either an amalgam containing the adverbial units 'imdi $>$ amdi $>$ emdi' or the rest of the simple past form ärti 'were' from the verb <-är/-er> 'to be' respectively'.

Below is a synopsis of studies, hypotheses as well as entries and descriptions in grammars followed by a digest of detailed analysis of the phenomenon, at some points listing the main areas of use and occurrence of $<\mathrm{Vol}+-$ (i)di $>$ constructions in Turkic.

Guzev [24, p.215-216] describes the morphological markers -sIndI/-(y)ImdI/-(y) IndI in Turkish, making a reference to the two further studies, that of Starostov [1, p. 106-118], and that of Kononov [2, p. 14-20]. Further grammarians such as Lewis [15, p. 138], Deny [25, p. 646-648] as well as Ediskun [26, p. 185] and Gencan [27, p. 269-270] also provide relevant information on the markers in question. However, Turkish reading book for foreigners of Tietze\&Lisie [28], contains constructions with this morphologic compound. The following scholars discovered the use of $<$ Vol+-(i)di $>$ in older Turkic texts. Gabain von [29, p. 134], while describing special constructions that express irreal semantics in Old Turkic, specified several markers, which are appropriate for the purpose, including the morphologic compounds <-(y)AyIn/-zUn +-ärti/or ärgäy $>$. However, Rentzsch $[30 ; 31$, p. 220] emphasizes combinations of operators and states that most of the modality operators occur in combination with tense markers and the voluntative in the 3th person singular as well, such as an example from Standard Turkish: çżzebiliyorsa kendi başına çözsündü bu gizemi 'if he could/can solve this mystery, he should solve it alone'.

${ }^{4}$ And yet please note a representative case for instance, for Ottoman Turkish [22, p. 192-193]; it is stated that "[...] unaccentable copula particles can be added to nominal and to some verbal predicates to alter the tense, mood, or syntactic independency of the predication; they occur in most cases between the thematic marker and the personal marker. Thus, idi signals past tense."

${ }^{5}$ See also Clauson [23, p. 193-194] and his references to the paradigms <-idi/-edi/-ädi>. 
Brockelmann [32, p.357] in particular drew attention to desiderative paradigms or verb stems, which are marked with the index -sIndI in al-Kāšgarìs Dìwān.

Further, Erdal [33, p. 521-523, 267; 34, p. 523], Brockelmann [35, p. 241] as well as Kondratjev [36, p. 89-90] analyzed the verb form <ärti> as an auxiliary verb in Old Turkic texts and provide various examples, specifying at the same time numerous relevant data on <ärti > in its auxiliary function. ${ }^{6}$ However, particular attention was given to the marker $<$-sIn+-idi> in the study of Juldašev [38] on analytical verb forms in Turkic languages. In similar way Menges [39, p.147-149] focuses in essence on the combinations expressing various modalities of actions that are rendered by the auxiliaries such as <ärti > following the main verb. Adamović [17, p. 218-219] identifies further, the paradigm -idi as an ancient preterit form in its grammatical function as an auxiliary verb ärdi or ärti occurring very frequently in Old Turkic inscriptions and manuscripts.

Certain dictionaries, such as the Uighur dictionaries by Röhrborn [40;41], provide us with relevant information on $<\mathrm{Vol}+-(\mathrm{i}) \mathrm{di}\rangle$. In the historical dictionary of Turkic languages documenting linguistic data from the $14^{\text {th }}$ century onwards, Nadžip [42, p. 126-127] makes an important remark that a defective verb -är/-er/-e 'to be' can occur only in a modal semantic. In the contexts featuring $<\mathrm{Vol}+-$ (i)di $>$, entries for the units 'imdi $>$ amdi $>$ emdi', as in 'now, at the moment, right away, immediately' are found in the dictionary by Sevortjan [43, p. 357-358] as well as in the glossary by Wilkens [37, p.913-914]. Grunina [20, p. 43] however, examining the history of the Turkic optative, analyses the aoristic value in the optative and mentions shortly -sIndI as a very rare Turkish marker in the example gelsindi.

Let take a closer look at the works mentioned above.

Starostov [1, p.114-117] in his pioneering study on the so-called unimplemented properties of Turkish in the existent Turkish grammars focuses in particular on the affixes <-sIndI/-sInlardI >. He pointed two application areas for both these markers:

a) Actions in the Past Perfect, for instance niçin yapmasınd $\imath$ 'why would not he do this (at that time)' or ne yapsind $\boldsymbol{\imath}$ ?, what should he have done?

b) In the literary narrative, when a kind of a linguistic approach is needed to provide a speaker's inner monologue.

Considering a relatively recent vintage of these paradigms the author notes at the same time that the affix - $\mathrm{dI}$ as a Past Perfect marker can be attached to the words which are usually not marked with the temporal suffixes, such as in aferin(di) or aşk olsun(du), 'bravo/well done'.

Further, Kononov [2, p. 14-20] continuing to investigate the marker $<-$ sIndI $>$ points out that the composed index <-zIn ärti $>$ as a historical analogue of the index <-sIndI> was already attested in the Old Uighur texts, for instance in 'Altun Yaruk. He states however, that the affix -sIn forms utterances expressing wish, necessity as well as possibility and therefore, is closely intertwined with the imperative, desiderative and optative moods. Kononov [2, p. 17-19] further touches upon various semantics of <-sIndI 3.Person singular/-yImdI for the 1.Person singular $>$, specifying examples as:

(a) Expressing an unrealised intention in the Past;

(b) Describing an action aimed in the Past, Present or Future tenses, in combination with the words diye 'saying', kim 'who', neden, ne diye, niçin 'why', etc.;

${ }^{6}$ On -är 'to be' as an auxiliary verb with the Aorist in the meanings a) 'to use to do something'; b) conditional with nominals 'in regarding ...' see Wilkens [37]. 
(c) Expressing presumption, speculation, and apprehension in the Past, for instance in constructions containing <-yor+-sIndI >, and <-mIş - $(\mathrm{mA})$ sIndI $>$ etc.

Gabain von [29, p.134] further indicates the utterances with the markers $<-(y) A y I n /-z U n+$-ärti/or ärgäy> as desiderative and gives numerous examples from Turkic Buddhist texts: körmayin ärti muni täg uluү äčì ämgäkig 'If only I had not experienced this great bitter suffering'; [...] ädrïlyuluq ämgäk bolmazun ärti 'sorrow of divorce should not rise' etc.

Guzev in his Turkish Grammar [24, p.215-216] refers to the affix -sIndI as an Imperative in Past tense, which consists of -sIn for the Imperative 3.Person Sg and - $\mathrm{dI}$ for the Past tense marker. Bringing numerous examples from the modern Turkish literature such as kimler bağırmıştı böyle çıksınlardı ortaya 'who has (so) shouted? They should come forward' etc., he notes that the complex affix -sIndI in Turkish is very extraordinary since it represents a combination of the mood and tense markers. However, the author categorizes the -sIndI as a morphologic resource with a complex semantic content in which -sIn indicates the necessity and -di suggests an action in the Past. Moreover, the author notes out that the facts provided in the study by Kononov mentioned above demonstrate certain capabilities of the form $<$ Vol+-(i)di $>$ to convey different meanings, such as unfulfilled intent in the Past', as well as 'prediction or probability' etc.

Moreover, there are also entries in the Turkish grammars.

As for the indexes -(y)ImdI or -(y)IndI, Lewis [15, p. 138], however, describes these in examples such as durundu 'hey, stop' or bakınd $\boldsymbol{\imath}$ 'hey, look here' as a colloquial imperative in Turkish which is compounded of the second-singular imperative dur, bak and the adverb imdi 'now'. Similar to Lewis, a Turkish Grammar by Ediskun [26, p. 185-186] illustrates similar examples from the colloquial Turkish such as bilsindi, gelsindi for the third person singular as well as okuyundu, deyindi, vurundu or gidindi for the second person singular having imperative semantics with nuances of necessity. Referring to the origin of -(i)di in the paradigms -(y)IndI or -sIndI Ediskun considers two possible ideas. Firstly, he assumes that it might be a derivation from the units emdi/imdi in the meaning of Turkish şimdi 'now, at present'; secondly, it is conceivable for him that the interjection haydi (=hadi) 'go, let' could have also played a role here, for instance in: gelin di, desin $d i .^{7}$ In the same manner, Deny [25, p.646-648] treats the paradigms in discussion. The scholar pointed out that $<-$ sIndI $>$ or $<\mathrm{i}(\mathrm{m} / \mathrm{n}) \mathrm{di}>$, respectively occur both in older Turkic texts from the older development stages of Turkic, for instance in the language of the book Divanū Lugati't-Türk but are also well known from several Ottoman Turkish texts. ${ }^{8}$

Gencan [27, p. 270] however, emphases the role of the word <imdi>, which together with imperative markers intensifies the speaker's encouragement to take an action. Gencan makes a relevant remark that <imdi> affects the imperative utterance and provides it with a volitional nuance with the meaning hayd $ı$ artık 'come on, let (do)'. Furthermore, Gencan described so-called eski şekil [old forms] in which occur both units <imdi> and

7 “(1) Türkçe’de şimdi anlamına gelen bir imdi (emdi) kelimesi vardır; [...] -(y)indi, -(y)ındı, -(y)ündü, -(u)ndu kelimelirinin emir kipinin II.tekil kişisine ulandığı, bu emrin, bu bileşimden oluştuğu düşünelebilir: gelindi — okuyundu — vurundu — tutundu — ağlayindi ... gibi. (2) Haydi! (=hadi) anlamına gelen di ile emir kipinin II. ve III kişilerinin bileşimden oluştuğu da benimsenebilir: gelin di, okuyun du, desin de ..." [26, p. 185]

${ }^{8}$ Another interesting observation by Deny is the prepositional occurrence of -di, for instance in $<d e$ imdi> [25, p. 647]. 
$<$ indi>, for instance: a) dedi Kayser durun imdi Malatyaya varun imdi (from Battal Gazi); (b) ur indi yüzün izine derviş (from Şeyhi XV) etc. Moreover, the author undertakes further to amalgamate forms appearing in the Turkish colloquial language such as bakınd 'look (at that, please)' etc. In the context of the units emdi/imdi, Kononov [2, p. 20] and Ediskun [26, p. 185] continue to analyze the contamination of ' $m>n$ ' from 'imdi' to 'indi', classifying it as a result from the dissimilation of the consonant pair ' $\mathbf{m d}>\mathbf{n d} \mathbf{d}$ '.

Sevortjan [43, p. 357-358] however, defines the units 'imdi>amdi>emdi' as adverbs having about 10 meanings in different Turkic languages, to name but a few: a) now/at the present; b) then/later; c) in that case; d) if/when; e) already; f) all right; etc.

Meanings of the units 'imdi>amdi>emdi' such as 'all right' or 'though/but' as it is also noted by Kononov [2, p. 20] presuppose an effort to look for any further explanations on the origin of the enclitic formant $<$-indi $>$.

The following scholars explicitly touched upon the issue of the origin of -(i)di in the morphologic compound. Kononov [2, p. 15] in several examples from the Old-Ottoman bilsün or bilsin idi identifies -(i)di as both the Past tense marker -dI as well as the Past copula -idi. Deny [25, p.646-648] as well as Ediskun [26, p. 185-186] however, assumed a derivation of $-\mathrm{dI}$ in $<\mathrm{Vol}+-(\mathrm{i}) \mathrm{di}>$ from the adverbial word $<\mathrm{ha}(\mathrm{y}) \mathrm{di}>$. Contrary to Lewis and Kononov, little impressed by the latter hypotheses, Sevortjan [43, p. 357-358] highlights an assumption featuring interesting facts about the origin of - $\mathrm{dI}$ in the words $<$ indi/ imdi>, linking it at the same time to Turkic-Mongolic linguistic contacts ${ }^{10}$.

Wilkens [37, p.130] gives an example from the Old Uygur Buddhist texts Daśakarmapathāvadānamālā (shortly DKPAM): köräyin amti anin küçin küsünin in the meaning 'I want to see/to test his power now', which he defines as an assertion in Voluntative. To this example, I will refer again later.

A tentative resume from the review above reads as follows. The index -(i)di in the morphologic compound $<\mathrm{Vol}+$-(i)di $>$ was either considered as a tense marker from the verb form <ärti>, or its lexical origin was assumed from the splits of the adverbials 'imdi/ emdi' or 'haydi $>$. What we can see here, regardless of whether it is a link to verbal or nominal origin, the morphologic compound $<\mathrm{Vol}+-(\mathrm{i}) \mathrm{di}>$ undoubtedly is a case of interaction of the (functionally different) grammatical/lexical categories in Turkic ${ }^{11}$.

Studies below do not discuss the origin of -(i)di in <-sUn/-zUn+-ärti $>$ in Old and Middle Turkic and consider it merely as the Past tense marker -ti/-di from the verb stem er-/är- 'to be'. Furthermore, the issue has drawn an attention of the scholars such as Erdal [33], Brockelmann [35], Kondratjev [36], Adamović [17], and Juldašev [38].

Erdal [33, p. 244-246, 267], however, describes verb combinations in Old Turkic, referring to them as analytical verbs, which appear in verb phrases with two verbs, with a possibility for one of them to be grammatical to varying degrees, having partly grammatical or/and partly lexical meaning. Complex verb phrases of that kind in Old Turkic were necessary for expressing categories such as tense, taxis, actionality, intention, ability, version, status, epistemic and deontic mood or for undergoing subordination in conditional

9 See also Ramstedt [44]: $\$ 14$ describes the word imdi as a compound noun consisting of the root morpheme '-Am/-Im' 'the present moment/now' and the affix - $\mathrm{dI}$ that forms adverbs from nouns.

10 See also in Grønbech's Komanisches Wörterbuch [45, p. 88] entries on the units <emdi, imdi> in the meanings as 'now, immediately, soon'.

11 On issue of (verbal) category interactions, 'infelicitous combinations' where two morphological indexes are functionally incompatible, and therefore a combination of these values is systematically excluded, reader is referred to typological studies by Xrakovskij [46], Malchukov [47]. 
or converb clauses. A non-first verb marked by the form -är 'to be' occurred in such cases in its preterit form -ärti. Exploring the nature of <-ärti> in Old Turkic, Erdal notes that it can be added also to the first and third persons volitional forms to express irreal wishes, for instance [...] sizni birlä körzün ärti [...] yörïzun ärti ' [...] 'together with you he would have seen, he would have lived'; körmäyin arti 'I wish I had not seen' etc. [33, p. 267, 521-524]. Moreover, the author points out that compounding the first and third persons imperative with <-ärti> can give to expressing of real wishes a more polite expression, such as in: maytri burxan bizni körzün ärti 'if only Buddha Maitreya would see us!'12 The index -(i)di however, can occur also as a part of the verb phrase but also can be situated in tense-aspect system as well as in analytical constructions expressing actionality, intention, ability or version [33, p. 245, 262-263].

Like Erdal, further dealing with the Old Turkic moods, Kondratjev [36, p. 89-90] touches upon the combination of the third person imperative and the first person voluntative with the verbal form <-ärti>, which consists of the verb -är 'to be' and the definite past paradigm - $\mathrm{dI} /-\mathrm{tI}^{13}$. In examples such us: a) yer yarulzun ärti 'oh, if the earth were to burst!'; b) yerkä kiräyin ärti 'oh, if I could have been swallowed!' the scholar also emphasised that the combination <-zUn+ärti> for the 3.Singular or <-yin+ärti $>$ for the 1. Singular transfer the wish meaning into the Past or Future zones, providing it with an irreal semantic.

Further, both studies of Brockelmann [32, p. 357; 35, p. 241] deal with Old Turkic and Islamic literary languages in Central Asia. The special focus here is on optative and counterfactual moods where the author emphases the role of the Past forms <ärdi/-irdi/-idi> from the verb -är 'to be'. He examines the phenomenon and gives several examples such as uluysïndi 'he should be bigger' etc., taking from al-Kāšgarī’s Dīwān [32, p. 357] ${ }^{14}$.

The combinations expressing various modalities of actions in combinations with auxiliary verbs following the main verb is an issue dealt with in Menges [39, p. 147-149]. He concerns himself in particular with irrealis and potentialis, which in Uighur are expressed by means of the combination <tense: the perfect indefinite + mood: the optative future of $-\ddot{a}(r)>$. Menges goes on to emphasise, the capability of the Uighur imperative to be composed with -ärgäy or -ärti to express irreality. He highlights the issue taking examples from von Gabain [32] such as: kör-mäyin ärti munu täg ulug ämgäkig 'Oh, had I never experienced such great bitter suffering!' or jir jarut-zun ärti! Jirkä kir-äyin ärti! 'Oh, let/ would the earth split, I wish, I would sink into the earth!'15

12 Erdal [33, p.524] adduces further examples from Röhrborn's Uigurisches Wörterbuch [41, p. 405, $\$ 24]$ for -är; -ärti which remains in the singular also when the lexical verb is plural. The unit -ärti is the preterit copula that can transfer the future taxis of Orkhon Inscriptions -dAčI into the past tense, for instance:

Türk bodun adak kamšattï, yavlak boltači ärti 'The Turk people tottered and were about to be routed, or Göl tekin yok ärsar kop öltāči ärtigiz 'If Kültekin did not exist you would all have eventually been killed'; cf. also Erdal [33. p. 245-246, 270].

${ }^{13}$ See Juldašev [38] on further different combinations of paradigms with -i(ä)di such as: -gAy -i(ä)di in Old Uigur, Altay, in Tuva as -gbAy ertik, in Karakalpak -gAn -edi etc.

${ }^{14}$ See Brockelmann [32, p. 240-241] with further examples from Yūknākỉs Hibat al-haqāiq et al.;

Brockelmann [35, p. 227-230] on the Voluntative -Ay or -Ayin that can appear with the marker -ärdi, for instance in halāk qülai ärdi - 'who wanted to destroy?'

Further studies should analyse the issue of reading diverse semantics, such as in Brockelmann's examples, in greater detail.

${ }_{15}$ Even though Menges notes that this usage in modern Turkic languages is not commonly employed [39, p. 149], the use of $<\mathrm{Vol}+-(\mathrm{i}) \mathrm{di}>$ as we have seen is still vivid in Cypriot Turkish. 
Adamović [17, p. 218-219, 297-298, 317-318], however, identifies an ancient preterit form 'ärdi or ärti' as <-idi> in grammatical function, being an auxiliary verb occurring very frequently already in Old Turkic inscriptions and manuscripts. In addition, the author notes that patterns with the temporal unit -idi consisting of tense and mood markers express irreal conditions or optative meanings, which have already significantly expanded the Turkic conjugation system during the first historical development phases. Juldašev [38, p. 211-212] however, examines Turkic complex analytical verb structures and deals in particular with the units <-sIn +-edi / $/ \mathrm{In}+$ ine $>$. The author specifies the semantic zones of its application such as for expressing desire for an action that has already happened or is happening at the moment as well as for expressing sorrow about impossibility of implementing any action. Examples from Tatar, such as alay bulmasïn ide, bulay bulmasïn ide [...] can be read either as '(I wish) it were not so and so', or '(alas), it could happen so, (alas) and could happen so ${ }^{16}$. Nadžip [42, p. 126-127, 412] further, in his historical dictionary of Turkic from the $14^{\text {th }}$ century describes the defective modal verb -är/-er/-e "to be". He accentuated its different modal semantics, such as conditional, appearing with the markers of the Simple Past, such as in sindī ärsa, 'when he would fall apart'17.

Finally, the look at dictionary entries revealed further facts about the active use and occurrence of the morphologic compound $<\mathrm{Vol}+$-(i)di $>$ in Turkic.

In the Uighur dictionaries by Röhrborn [40, p. 148, 151, 162; 41, p. 392, 394-395, 397, 401-403, 405], however, examples are quoted or mentioned of the entry -är(ti). It can occur in combinations together with verbs in Aorist, Past Perfect as well as with the verbs marked by the Voluntative -ayin for the first person singular and - zun for the third person singular. The semantic contents of these utterances are:

a) <would, were, should, would/could have been>;

b) irreal potential or conditional in Present or Past tenses/Preterit;

c) volitional;

d) for -zun+ärti also in the meaning <if only ... would + verb>;

e) potential optative preterit such as in mänilig kilayin ärti <if I only could make (you) happy!>; siizinä nä yaviz kilayin ärdi <I could kill you / should I kill you>; $t(\ddot{a}) n r i k a ̈ n i m(i) z$ uzun özin ... ärmäki bolzun ärti <if our ruler was to be blessed [with a long life] $>$ etc. $^{18}$

${ }^{16}$ On further complex verb forms with the auxiliary verb -är(ti), which completes the predicate features of a main verb as well as its temporal and modal parameters, see also Nasilov [48, p. 82-83; 49, p. 6465]. He analyses utterances from Old Turkic (Runic and Uigur texts] but also patterns from literary texts from the Islamic or Karachanid literary period respectively, such as Kutadgu Bilig and Atabat-al-hakaik. There are paradigms, for instance with the units $<(\mathrm{g}) \mathrm{Ay}+\mathrm{erdi} / \mathrm{edi}>$ in preterite optative constructions in $n e-$ cessitating imperfectum meanings expressing irreal or conditional actions: menin sözüm tutsaniz erdi, sizlerge bu emgek tegmegey erdi <you should hear of my words, (then) you would not be ill >.

${ }_{17}$ Nadžip translates the example into Russian as 'когда он разбился' <as he fallen apart>; another possible reading could be also 'when/if he would fall apart'; further studies should also here analyse the issue of reading diverse semantics in greater detail.

18 Additionally, in Clauson's dictionary [23, p. 193-194], there are entries on -er 'to be' also in forms -i:di: and -erdi: as well as on -idi and -di as auxiliary verbs. The author emphasises a very common use of these forms in Old Turkic texts; the occurrence of the morphologic compound $<$ mood+tense $>$ is not specified more widely.

Middle Turkic texts such as in Codex Cumanicus attest several forms of the verb -er as -ür or e- in the Past paradigm <-erdi, -edi $>$ together with numerous affixes, for instance, aspectual -r edim, temporal -dIm +-edi, -mIš edim, as well as modal - $\gamma$ aj edim [45, p. 89-91]. The modal morphologic compound <- $\gamma$ aj 


\section{Methodological frames of the study}

The approach 'from meaning to form' by Bondarko [3] was chosen for the methodological principal of the present work. The reasons why this approach was selected will be explained below. First, the functional grammar approach 'from meaning to form', in other words, analysis proceeding from semantic contents and aimed at finding various means of its expression makes it possible to identify the particularly complex means (combined, grammatical-lexical, grammatical-contextual, oblique, indirect, "hidden" in complex laws of interplay of grammar and vocabulary, grammar and context, morphology and syntax etc.). Another reason is that it enables one to integrate in a single system the diverse language means which traditional form-based grammar analyses in different parts of grammatical description - morphology, word-formation, and syntax. ${ }^{19}$ However, the main reason for applying Bondarko's approach 'from meanings to form/means' is that it corresponds to the speaker's point of view, whereas analyses 'from means to functions or meanings' correspond to that of the listener [50, p. 13].

In previous investigations on $\mathrm{CT}<\mathrm{Vol}+-(\mathrm{i}) \mathrm{di}>$ constructions scholars thus, were in fact, listener describing CT morphologic means and modality of a spoken language from perspectives based on the Standard Turkish templates. Thus, the approach allows us to better understand and interpret several meanings that the CT speaker can express applying the grammatical means $<\mathrm{Vol}+-(\mathrm{i}) \mathrm{di}>$ on the one hand, and what his/her view of events is, on the other hand. And yet it does not matter, whether the morphologic compound coincides with the data in Standard Turkish. Of primary interest also is the case that we face at the same time a specific semantic-grammatical circumstance in CT where the voluntative mood can intertwine either with the temporal or nominal relations. The analysis and reading of CT examples created by the grammatical means $<\mathrm{Vol}+-(\mathrm{i}) \mathrm{di}\rangle$ will be systematized below according to their modally and temporally coloured meanings (necessity, possibility, volition, purpose, incentive nuances, concession etc.)

\section{Semantics of the grammatical morphologic compound $<$ Vol+-(i)di $>$ in Cypriot Turkish}

The data I report clearly show that the marker $<\mathrm{Vol}+-(\mathrm{i}) \mathrm{di}>$ may have in CT more than one semantic which I analyze here from the CT speaker perspective.

(1) san- ma- $m$ bu hafta işle-sindi

think-NEG-PRS-1SG this week work-VOL/supp-3SG

I don't think (that) (s)he is working this week / she should work this week

(2) gid-erdi Larnaka-ya de-rdi oğren-eyimdi Rumcayī

go- IMPV-3SG Larnaca-to say-IMPV-3SG learn-VOL/des-1SG Greek

(S)he used to go to Larnaca (and) used to say I want/would like to learn Greek

\footnotetext{
edim> is defined in Gabain [29, p. 134] as a synonym for the morphologic compound <-AyIn/-zUn +-ärti> expressing irreal modalities in Old Turkic texts.

${ }^{19}$ See Bondarko [3, p.20] on the importance of the study of semantic categories in their relation to grammatical categories and other linguistic means for functional grammar.
} 
In the example, (1) a nuance of a (strong) supposition as well as referring to a possible action can be observed, also not least because of the verb <sanmak $>$ 'to think, to guess', while in the example (2) a wish tendency or a desired objective to learn Greek by a person is indicated. In addition, intention and necessity in the Future are further possible interpretations.

The utterances above therefore, can be understood as follows:

(1a) 'I don't think whether (s)he would work this week', but also depending on the context as an (external) necessity

(1b) 'I don't think (s)he has to work / she must work this week'

(2a) 'I have to learn Greek (now, finally)'

(2b) 'I am going to learn Greek'

(2c) 'I would like to learn Greek'

(2d) 'I should learn Greek'.

The following reading is also possible:

(2e) 'Let me learn Greek (finally)'.

As such they cover the part of the semantic domain of actions which is are/going be/ will/should be done/has to be done' in the present or also in the future ${ }^{20}$. However, when reading in different tenses, it is important to keep an eye also on the so-called satellite verbs, which, on the one hand, can refer to the aspect and tense of actions, and, on the other hand, can have certain semantic meanings ${ }^{21}$. Let us have a look at the examples expressing hope, possibility, opinion, direction etc. toward an action which is wished, desired but has not (yet) occurred or an action which would, might as well, or could have been performed by the speaker himself or by a third person. In the examples below the marker $<$ Vol+-(i)di $>$ expresses both the desired or irreal meanings. Moreover, among these examples there are CT constructions that appear with the verb isde- 'to want/to wish', intensifying the volition or desiderative patterns:

(A) Indicating an expected state or ask rhetorically with the sense of necessity:

(3) gadīnī sučla-yìmdī isten? woman-ACC blame-VOL/neces-1SG want you Do you want me to blame the woman? / Should I blame the woman?'

(B) Indicating a desirable state or expressing a purpose:

(4) iste-dim ben-de want-PAST-1SG I-LOC I wanted (though/that) she would gal-sīndì stay-VOL/IRRwish-3SG

${ }^{20}$ This is widely known also in other Turkic languages, for instance in Tatar [51], Azerbaijani [52, p. 161-188].

21 See Johanson [53, p. 40, 58-66] on the actional phrase which is both a functional term and the linguistic unit that encodes the semantic properties of a given actional content consisting of the verb (possibly including actionality operators) and its arguments and satellites ('obligatory and facultative complements'). 
(5) iste-r-ler (h)aa ikna ed-eyimdi onnar-ī want-AOR-3PL ha persuade-VOL/IRRwish-1SG them-ACC

They really want (though/that) I could/would/should persuaded them

(6) isterik da bir Gìbrīs ol-sundu want-1PL really one Cyprus become-VOL/IRRwish-3SG We want really (that) Cyprus would / should became one

(7) insan Yunanca ve Türkce bil-sindi people Greek and Turkish know-VOL/IRRwish-3SG

$\begin{array}{lll}\text { birbirini } & \text { anna-sīndī } & \text { isde-rim } \\ \text { each other } & \text { understand-VOL/IRRwish-3SG } & \text { wish-AOR-1SG }\end{array}$

I wish (however/that) people would know / should have known/ Greek and Turkish, understand each other'

(C) Indicating uncomfortable feelings, necessity:

(8) emin-di git-sindi oraš-dan sure-PAST-3SG go-VOL/neces-3SG there-ABL $\mathrm{S}(\mathrm{h}) \mathrm{e}$ was sure he must go from there

Additionally, purpose or incentive (here from the perspective of the third person), CT speaker expresses wish nuances, as well as necessities, in the following examples:

(9) der git-me-sindi ev-e says-1S go-NEG-VOL/neces-3SG home-DIR $\mathrm{S}$ (h)e says (that) (s)he should not go home'

(10) ara-r ben-i Limasol'dan arkadaş-im calls-AOR-3SG me-ACC Limasol-ABL friend-POSS-1SG gid-eyimdi oraya da yemek ye-yimdi go- VOL/incen-1SG over there and dinner eat-VOL/incen-1SG

My friend calls me from Limasol and wants me to come over to have dinner

Thus, Cypriot Turkish owns the specific and Old Turkic manner to convey a pallet of semantic values from real and unreal wishes but also intentions and desires as well as expectations, suppositions and necessities by means of $<\mathrm{Vol}+$-(i) di $>$, which was, as we have seen, actively used already at early development stages of Turkic. In analogue to different Turkic languages however, by means of this marker the CT speaker can express also emotive meanings, ${ }^{22}$ for instance isterim proplem çözsindi 'I wish he could/would/should solve

22 See Agazade [52, p. 190] on emotionally saturated volitional expressions and Azerbaijanian suffixes, expressing a higher degree of emotionality. 
a problem' at the same time indicating a condition such as behavior or competence as well as the (internal) skill of a person. The semantic abundance in all above-given examples is context-sensitive and per se highly manifold emotionally and therefore, open to semantic interpretations, including those for different tense and mood/modality readings.

\section{6. $<$ Vol+-dA $>$ semantics in Turkmen}

Below is the material from the Turkmen language data bank that was collected during fieldwork in Turkmenistan. The morphology stock of a Turkmen speaker includes diverse markers to express equivalent semantics such as necessity, wish or permission. So, let us first look more closely at the means in Turkmen where probably analogous compositions as $\mathrm{CT}<\mathrm{Vol}+$-(i)di $>$ are present. The Turkmen speaker uses, in fact, similar morphologic compounds except for the second index, instead of -(i)di we meet the particle -dA:

(A) the 3. Singular -sInd $A<$ Voluntative $+-\mathrm{dA}>$, such as:

(1) gel-sin $\boldsymbol{d} \ddot{a}$, articulated because of the consonant assimilation $<\mathrm{nd}=\mathrm{nn}>$ as <gelsinnä>; depends on the intonation and context:

(1a) 'let him come', well known semantic in common Turkic

(1b) '(s)he has to come', 's(h)e should come' in necessitating meaning

(1c) 'I wish she would/could come', volitive.

However, two special Turkmen features in that context should be mentioned, too. The first specific feature is that the vocal length plays a distinctive role in expressing modality:

(B) the 1. Singular -AýIndA $<$ Voluntative+-dA $>$ :

(2) al-aýïn da pronounced as <alayīnna>

(2a) 'let me take'

(2b) 'I should/want to take'

(2c) interrogative and asking permission lengthened al-a:ýï $\boldsymbol{d a}$ 'may I take?'

The second feature relates to the speaker's point of view by qualifying the action. A Turkmen speaker, thus, when expressing a subjectively desirable action uses a double mood marking $<$ Optative + (Imperative) $/$ Voluntative + -dA $>:^{23}$

(C) the 3. Singular -AýsIndA <Optative+ (Imperative)/Voluntative +-dA $>$ :

(3) gel-äýsin dä, articulated as <geläýsinnä>

(3a) 'I wish, she would visit (us)'

(3b) '(I wish), she could/would come'.

Finally, the presence of several lexical instruments for the corresponding meanings completes the picture. Examples below illustrate these issues in Turkmen:

${ }^{23}$ In Turkmen there is also the 2.SG -AýdA <Optative +-dA > such as in: al-aýda '(I beg you) to take (it) / (I wish) you would/could take (it) / please, take (it).

See studies of Blagova [54, p. 10-25], Guzev [55, p. 92-99], Ščerbak [56, p. 43-45, 52-57] on the oldest mood markers (optative/voluntative) such the affixes -A(y)Im/-sIn in Old-Turkic, Old-Anatolian Turkic etc. expressing desire, intention, request, lust and command. 
(C) <indi $>$ 'now' in $<$ Imperative 2 . Sg + lexical /indi $>$ :

(5) dur indi articulated as $<$ dur-inni $>$ 'stop now'

(5a) 'you have to stop'

(5b) 'you should stop'

(D) $<$ indi $>$ in $<$ (Imperative 2. Sg) + Optative + indi $>$ :

(6) duraý indi < dur-aýinni> 'you may stop'

(6a) 'I want you (would) stop'

(6b) okaý indi <okay-inni> '(please) read now/finally; (so), you can/may read now'

Moreover, such an utterance as: o da näme et-sin dä? 'what should s(h)e do?' can be heard often in colloquial Turkmen. I shall once again refer to the compound $<$ moods $+-\mathrm{dA}>$ and its semantics in Turkmen, with special focus on the particle -dA, in conclusion/discussion part below.

\section{Conclusion and discussion}

By taking into account, especially a diachronic perspective (Old and Middle Turkic texts) but also studies, entries in grammar books as well as realities in other Turkic languages, such as Turkmen, I conclude the following. The complex marker $<$ Vol+-(i)di $>$, which is still applied in CT to express different modalities, is of Turkic origin and not a recent Greek contact-induced phenomenon as has been assumed in previous investigations. The morphologic compound is still very vital and active in Cypriot Turkish.

The grammatical composition <Voluntative + tense(?)/nominal(?)> as specified by Guzev above is very extraordinary. It is moreover, also irritating for the ST listener since this compound illustrates a combination of functionally incompatible grammatical categories. This viewpoint might be a reason among others to belief for previous scholars in the contact-induced nature of $<\mathrm{Vol}+$-(i)di $>$ in CT.

Beyond the specificity of the subject addressed in this paper, the examination of application areas of this marker in the earlier stages of Turkic development further demonstrated, that a blend between the mood and the tense in form of historical -ärti or -(i)di as well as, probably, between the lexical units <indi, imdi, haydi(?)> in Turkic, was and still remains semantically motivated in CT; semantic meanings evidenced both in CT or in the Old and Middle Turkic are therefore, highly varied. Examples from CT, Old Turkic or Turkmen illustrate not only an exemplary case in particular, but also regarding diachronic paths of Turkic in general, that through the compound of $<\mathrm{Vol}+-(\mathrm{i}) \mathrm{di}>$ alone the speaker can convey complex semantics or more precisely indicate modal concepts such as obligation, probability, and possibility as well as real and irreal wishes, etc. The versatility of $<\mathrm{Vol}+-$ (i)di $>$ thus resolves the viewpoint as to incompatibility of grammar categories in Turkic mood/voluntative with -(i)di; with regard to the latter it seems to be a remnant of either a verb or, quite possible, a split noun.

Moreover, the link to other Oghuz languages, such as Turkmen as spoken in Turkmenistan, demonstrates analogous formations for expressing semantics such as advice, suggestion, obligation/necessity, probability, asking permission, irreal wishes, etc. The Turkmen speaker has in his inventory not only analagous compound of $<\mathrm{Vol}+-\mathrm{dA}\rangle$ but also a further tool - the vocal length, which plays a distinctive role in semantics. 
As regards the origin of Turkmen - $\mathrm{dA}$ it remains very much open to further discussion. As we have seen, the nature of the -(i)di in $<\mathrm{Vol}+-$ (i)di $>$ Turkic or Turkish respectively is conceived of by hypothesizing that it either could be a) Past tense marker and/or Past copula or b) linked to the adverbs 'emdi/indi', as well as c) the last remaining syllable from the word $\langle$ haydi $\rangle$. What is the origin of $-\mathrm{dA}$ in Turkmen $\langle\mathrm{Vol}+-\mathrm{dA}\rangle$ ?

Apart from its conjunctive function as <and / also / too $>$ on the one hand it certainly looks like an enclitic. If that is the case, then it functions as an intensifier that the speaker uses to strengthen his wish, (asking) permission, obligation or necessity. On the other hand, the possible strong influence of the adverb 'indi' on the origin of - $\mathrm{dA}$ in Turkmen $\langle\mathrm{Vol}+-\mathrm{dA}\rangle$ may not be dismissed, since the semantics of the utterances gelsindä, expressing necessity, or geleýindä, expressing intention can be also expressed as gelsin indi or geleýin indi $i^{24}$. Referring again to the use of amti in Old Uygur Buddhist texts [37, p. 130] the example: köräyin amti anin küçin küsünin 'I want to see/to test his power now' demonstrates interfaces with the use of indi in Turkmen with the 1.Person voluntative in: göreyin indi 'I want to see / let me see from now on' but also in the reading '(you do/ make it so) that I can see (it) from now on'. Concerning functions of Turkish -dA in different contexts [58, p. 101] it is known that it can appear in various combinations, for instance with a form containing the possibility suffix -(y)Abil or it can be inserted after -(y)A in colloquial Turkish speech, such as in bakabilirim de or baka da bilirim 'I can also look. The authors state further, that -dA can also occur as a clitic or a conjunctive and discourse connective with additive as well as adversative, continuative/topic-shifting and enumerating marker. The stress also plays an important role in some of the - $\mathrm{dA}$ functions $[58, \text { p. } 404]^{25}$.

In the context of the Turkmen particle - $\mathrm{dA}$, having voluntative/optative/imperative markers, observations made by Erdal on both Old Turkic and Turkish seem to be relevant, as well. In Turkic Manchæan texts, Erdal [33, p. 236] illustrates a blend between the imperative suffix -zUn in the third person and other suffixes such as an instrumental form anïn 'thereby', which over time developed into the combination -zUnIn to express wishes, for instance in: [...] küčlüg prištilär küč berzünin 'may the powerful angels give us strength'. Further, Erdal makes another observation on the realisation of "wish" expressed by the imperative as well as other suffixes highlighting an example from the Standard Turkish: Tanri izin versin de artık ayrilmıyalım 'may God allow this (and) we won't break up'.

An assumption thus solicits itself that the Turkmen paradigm <-sIndA/-(Aý)IndA> could be an amalgam, where - $\mathrm{dA}$ might be also a slip from any relevant suffix. All provided data above illustrate that the phenomenon 'co-occurrence of mood with verb/tense or noun/lexical units $>$ in order to create different semantics should be discussed and compared initially between Turkic languages from both diachronic and synchronic as well as inter-typological realities. Here, there are only some examples from other Turkic varieties such as Iranian Turkic, which shows attention grabbing blends of different grammatical categories: a) gedimday, b) degimdaynan and c) gedimdaynandi` 'let me go / please, let me go / I would go / I should go' or d) qoy aparsinday 'he should take / let him take / (s)he has

${ }^{24}$ In the Turkic literary texts from the 11th century such as in Kutadgu bilig by Yūsuf Khāșș-Hājib Balasagun the units <emdi/imdi > with -AyIm can be found in abundance, for instance: basa aydim emdi bu ay toldini ' 'in the beginning/so now I tell/I would like to tell about Ay-Toldì [57, p. 50-51].

25 On Turkish -dA see also in: Göksel Aslı, Örsoy Sumru A. 'dA: a focus/topic associated critic in Turkish' // Linqua. 2003. No. 113. P.1143-1167. 
a permission to take. The latter expression sounds and looks like alsyndaý in colloquial Turkmen, articulated as < alsinnnaý > and reads as 'let him take (because I do not mind/this no longer bothers me)'26.

As for studies comparing Cypriot Turkish not only with Standard Turkish in general, but also more broadly considering it in light of mood/modality expressions, we have to bear in mind that Standard Turkish was immensely influenced by the language reform in the beginning of the 20th century. In terms of linguistic studies, contrasting Cypriot Turkish and Cypriot Greek, especially in the field of morphology and syntax, as well as hypothesizing the Cypriot Greek influence, for instance on CT mood formations, we should be mindful of the following aspects. There is a gap between studies which deal, among other topics, with the CT-CG written or lived bilingualism from historical, i. e. Ottoman-Cypriot Greek language aspects, on the one hand, and with analyses of its linguistic and socio-linguistic consequences, such as code-switching or language(s)-mixture, on the other hand. These aspects, being precursors of morphology or syntax changes under CT-CG contact circumstances, have yet to be investigated ${ }^{27}$. Thus, among several remaining questions when assuming possible CT-CG mood contacts it is important to consider, sociological, linguistic, psycholinguistic etc. factors, which could or have led Cypriot Turkish to relinquish its native origin (?) or pre-existed Turkic mood/modality registers. That is despite the fact that in the case of $<\mathrm{Vol}+-(\mathrm{i}) \mathrm{di}>$ constructions the assumption about a Greek influence on this formation in CT seems to be no longer an open issue. Nevertheless, studies on Turkic typological comprehensive grammars of moods and modality concepts should be continued. In the variety of Turkish spoken in Cyprus there is still an abundance of (lost historical) Turkic treasures waiting to be discovered.

\section{References}

1. Starostov L. N. O nekotorykh ne zafiksirovannykh v grammatikakh znacheniiakh turetskikh glagol'nykh form povelitel'no-zhelatel'nogo nakloneniia [On some grammatical meanings of the Turkish verb forms of the imperatively desirable mood]. Moscow, Nauka, 1971, pp. 114-117. (In Russian)

2. Kononov A. N. Zametki po morfologii turetskogo iazyka [Notes on the morphology of the Turkish language]. Sovetskaia tyurkologiia, 1980, no. 2, pp. 14-20. (In Russian)

3. Bondarko A. V. Funktsional'naia grammatika [Functional Grammar]. Leningrad, Nauka, 1984. (In Russian)

4. Sakhatova G. S. Apprehensive in Cypriot Turkish. Vestnik of Saint Petersburg University. Asian and African Studies, 2018, vol. 10, issue 3, pp. 315-329.

5. Sahatova G.S. Morphologie und Semantik der "vermittelten" Evidentialität” im Zyperntürkischen. Ural-Altaische Jahrbücher, 2016, pp. 123-138.

6. Abdurrazak G. Y. The tense, aspect, mood-modality system of the Turkish spoken in Cyprus. A sociolinguistic perspective. London, SOAS, University of London, 2012.

7. Demir Nurettin. Kıbrıs'ta Türkçe [Turkish in Cyprus]. Öztoprak Nihat, \& Kaya, Bayram Ali (eds). Suya düssen Sancak. Kıbrıs Türk Kültürü Üzerine İncelemeler, 2007, no. 47, pp. 60-79. (In Turkish)

8. Demir Nurettin. Sprachkontakt in Nordzypern? Bemerkungen zu gebundenen Sätzen. Einheit und Vielfalt in der türkischen Welt. Materialien der 5. Deutschen Turkologenkonferenz. Boeschoten H., Stein Heidi (eds). Wiesbaden, Harrassowitz, 2007, pp. 160-170.

9. Demir Nurettin, Johanson Lars. Dialect contact in Northern Cyprus. International Journal of the sociology of language, 2006, issue 181.

${ }^{26}$ I thank my colleague Naghmeh Naibzadeh who speaks many Turkic Iranian patois, and who provided me with the examples.

27 On moods in Turkic see in Johanson [59]; on copying reasons in Turkic see in Menges [39, p. 146147]. 
10. Duman Musa 1999. Kıbrıs ağzı üzerine bazı notlar [Some notes on the Cypriot Dialect]. İlmi Araştırmalar, 1999, no. 8, pp. 115-130. (In Turkish)

11. Gulle Ozan V. Structural borrowings in Cypriot Turkish from Cypriot Greek. Mediterranean Language Review, 2011, vol. 18, pp. 91-113.

12. Kappler M., Tsiplakou Stavroula. Is There a Common Cypriot Subjunctive? Mediterranean Language Review, 2015, no. 22, pp. 139-155.

13. Kappler M. Contact-induced effects in the syntax of Cypriot Turkish. Turkic Languages, 2008, 12/2, pp. 196-213.

14. Demir Nurettin. "Wollen" in Zyperntürkisch. Mediterranean Language Review, 2002, vol. 14, pp. 9-20.

15. Lewis G. L. Turkish Grammar. Oxford, Clarendon Press, 1967.

16. Johanson L. A synopsis of Turkic volitional moods. Turkic Languages, 2014, 18/2, pp. 19-53.

17. Adamovič M. Konjugationsgeschichte der Türkischen Sprache. Leiden, E. J. Brill, 1985.

18. Aslan Demir Sema. Türkçede İsteme Kipliği. Semantik-Pragmatik bir inceleme [Demand Modal in Turkish. A semantic-pragmatic review]. Ankara, Grafiker, 2008. (In Turkish)

19. Shcherbak A.M. Formy zhelatel'nogo nakloneniia v tiurkskikh iazykakh [Forms of the volition mood in Turkic languages]. Turcologica, 1976, pp. 184-190. (In Russian)

20. Grunina E. A. K istorii tyurkskogo optativa (na materiale oguzskih jazykov) [To the history of the Turkic optativa (on the material of the Oguz languages)]. Voprosy tyurkskoi fililogii, 2003, issue 5, pp. 33-51. (In Russian)

21. Demir Nurettin. Kıbrıs ağızları üzerine notlar [Notes on the dialects of Cyprus]. Scholarly depth and accurasy. Festschrift to Lars Johanson. Demir, Nurettin \& Turan, Fikret (edd.). Ankara, 2002, pp. 100-110. (In Turkish)

22. Kerslike Celia. Ottoman Turkish. Lars, Johanson and Éva Ágnes Csató (eds). The Turkic Languages. London, New York, Routledge, 1998, pp. 179-202.

23. Clauson G. An Etymological Dictionary of Pre-Thirteenth-Century Turkish. Oxford, At the Clarendon Press, 1972.

24. Guzev V.G. Teoreticheskaia grammatika turetskogo iazyka [Theoretical grammar of the Turkish language]. St. Petersburg, St. Petersburg University Press, 2015. (In Russian)

25. Deny Jean. Türk dili bilgisi [Grammer of Turkish language]. Istanbul, Kabalcı Yayınevi, 2012. (In Turkish)

26. Ediskun H. Yeni Türk Dilbilgisi [New grammar of Turkish language]. Istanbul, Remzi Kitabevi, 1985. (In Turkish)

27. Gencan T.N. Dilbilgisi [Grammar]. $3^{\text {rd }}$ ed. Istanbul, Türk Dili Kurumu, 1975. (In Turkish)

28. Tietze Andreas, Lisie Sura G. Türkisches Lesebuch für Ausländer. Istanbul, 1943.

29. Gabain von Annemarie. Alttürkische Grammatik. 3. Aufl. Wiesbaden, Otto Harrassowitz, 1974.

30. Rentzsch J. Modality in the Turkic languages. Form and meaning from a historical and comparative perspective. Berlin, 2015.

31. Rentzsch J. Zur Modalität im Türkischen. Turkologie in Mainz. Boeschoten H., Rentzsch J. (eds). Wiesbaden, 2010.

32. Brockelmann C. Buchbesprechung v. Gabain, A.von, Alttürkische Grammatik mit Bibliographie, Lesestücken und Wörterverzeichnis, auch Neutürkisch, mit vier Schrifttafeln und sieben Schriftproben. Zeitschrift der Deutschen Morgenländischen Gesellschaft. Leipzig, Kommissionsverlag F. A. Brockhaus, 1942, Band 96, S. 353-364.

33. Erdal M. A Grammar of Old Turkic. Leiden, Brill, 2004.

34. Erdal M. Old Turkic word formation. A functional approach to the lexicon. Vol. 1. Wiesbaden, Harrassowitz, 1991.

35. Brockelmann C. Osttürkische Grammatik der islamischen Literatursprachen Mittelasiens. Leiden, E. J. Brill, 1954.

36. Kondratjev V.G. Grammaticheskii stroi iazyka pamiatnikov drevnerusskoi pis'mennosti VIII-XI vv. [Grammatical formation in the Old Turkic texts in 8-1 $1^{\text {th }}$ century]. Leningrad, Izd-vo Leningradskogo Universiteta, 1981. (In Russian)

37. Wilkens Jens. Buddhistische Erzählungen aus dem alten Zentralasien. Edition der altuigurischen Daśakarmapathāvadānamālā. 3 Bde. Turnhout, 2016 (BT XXXVII).

38. Juldašev Ahnef A. Analiticheskie formy glagola $v$ tiurkskikh iazykakh [Analitical verb forms in Türkic languages]. Moscow, Nauka, 1965. (In Russian)

39. Menges K. H. The Turkic languages and peoples. An Introduction to Turkic studies. Wiesbaden, Harrassowitz, 1968. 
40. Röhrborn K. Uigurisches Wörterbuch. Sprachmaterial der vorislamischen türkischen Texte aus Zentralasien. I. Verben ab- -äzügla-, neubearbeitet. Stuttgart, Franz Steiner Verlag, 2010.

41. Röhrborn K. Uigurisches Wörterbuch. Sprachmaterial der vorislamischen türkischen Texte aus Zentralasien. Lieferung 6, ämgäksun- - ärnak. Wiesbaden, Franz Steiner Verlag GmbH, 1998.

42. Nadžip E. N. Istoriko-sravnitel'nyi slovar' tiurkskikh iazykov XIV veka na materiale Hosrau i Širin Kutba [Historical and Comparative Dictionary of Turkic Languages in $14^{\text {th }}$ century]. Vol. I. Moscow, Glavnaia redaktsiia vostochnoi literatury, 1979. (In Russian)

43. Sevortjan E. V. Etimologicheskii slovar' tiurkskikh iazykov [Etymology dictionary of Turkic languages]. Vol. I. Moscow, Nauka, 1974. (In Russian)

44. Ramstedt G. I. Vvedeniie v altaiskoe iazykoznaniie. Morfologiia [Intoduction to Altaic linguistics. Morphologie]. Moscow, Nauka, 1957. (In Russian)

45. Grønbech K. Komanisches Wörterbuch. Türkischer Wortindex zu Codex Cumanicus. Kopenhagen, Einar Munksgaard, 1942.

46. Xrakovskij V.S. Grammaticheskiie kategorii glagola: opyt teorii vzaimodeistviia [Grammatical categories of the verb: experience of interaction theory]. Mezhkategorial'nyie sv'azi v grammatike. Bondarko A. V. (ed.). St. Petersburg, Dmitrii Bulanin, 1996. (In Russian)

47. Malchukov A. L. Incompatible categories. Resolving the "present perfective paradox". Cross-linguistic Semantics of Tense, Aspect, and Modality. Hogeweg L., de Hoop H., Malchukov A. L. (eds). Amsterdam / Philadelphia, John Benjamins Publishing Company, 2009, pp. 13-32.

48. Nasilov V. M. Iazyk tiurkskikh pamiatnikov uigurskogo pis'ma XI-XV vv. [Language of the Turkic monuments of the Uyghur in 11-15 centuries]. Moscow, Nauka, 1974. (In Russian)

49. Nasilov V. M. Iazyk orkhono-eniseiskikh pamiatnikov [Language of Orkhon-Yeniseysky Monuments]. Moscow, Izd-vo Vostochnoj literatury, 1960. (In Russian)

50. Bondarko A. V. Functional grammar. A field approach. Transl. by Chulaki I. S. Amsterdam/Philadelphia, John Benjamins Publishing Company, 1991.

51. Tumaševa D. G. Glagol [Verb]. Sovremennyi tatarskii literaturnyi iazyk. Leksikologiia, Fonetika, Morfologiia [Contemporary Standard Tatar. Lexicology, Phonetic, Morphology]. Moscow, Nauka, 1969, pp. $210-$ 244. (In Russian)

52. Agazade N. G. Sistema glagol'nykh naklonenii v sovremennom azerbaidzhanskom literaturnom iazyke [System of modi in the Standard Aserbaidjanian]. Baku, Iz-vo Akademii nauk Azerbaidzhanskoi SSR, 1967. (In Russian)

53. Johanson L. Viewpoint operators in European languages. Tense and aspect in the languages of Europe. Ed. by Ö. Dahl. Berlin, New York, 2000, pp. 27-187.

54. Blagova G.F. Stroenie form zhelatel'nogo nakloneniia $\mathrm{v}$ tiurkskikh iazykakh i tendentsiia $\mathrm{k}$ sverkhnormal'nomu ikh ulozheniiu [Form design in volitional mood in Turkic languages and its tendency to supranormal complication]. Sovetskaia t’urkologiia, 1973, no. 1, pp. 10-25. (In Russian)

55. Guzev V. G. Ocherki po teorii tiurkskogo slovoslozheniia: Glagol (na materiale staroanatoliisko-tiurkskogo iazyka) [Essays on the theorie of the word formation in Turkic: Verb (on the Old-Anatolian Turkic material)]. Leningrad, 1990. (In Russian)

56. Ščerbak A. M. Ocherki po sravnitel'noi morfologii tiurkskikh iazykov: Glagol [Essays on the comparative morphology of Turkic languages: Verb]. Leningrad, 1981. (In Russian)

57. Kutadgu Bilig. Yusuf Has Hacib, çeviren Reşid Rahmeti Arat [Yusuf Has Hacib, traslated by Reşid Rahmeti Arat]. İstanbul, Kabalc1 Yayinevi, 2005. (In Turkish)

58. Göksel Asl, Kerslike Celia. Turkish. A Comprehensive Grammar. London, Routledge, 2005.

59. Johanson L. Mood meets mood: Turkic versus Indo-European. Morphologies in contact. Vanhove M., Stolz T., Urdze A., Otsuka Hitomi (eds). Berlin, Akademie Verlag, 2012, pp. 195-203.

Received: August 23, 2018

Accepted: March 26, 2019

Author's information:

Gulshen S. Sakhatova - Dr. Sci. in Philology; gulshen.sakhatova@uni-goettingen.de 


\title{
Заимствована ли форма < Волунтатив + -(i)di> в кипро-турецком языке? Ссылки на общетюркское происхождение
}

\author{
Г. С. Сахатова
}

Гёттингенский университет им. Георга-Августа, Германия, 37073, Гёттинген, Генрих-Дюкер-Вег, 14

Для цитирования: Sakhatova G. S. Is <Voluntative+-(i)di> in Cypriot Turkish contact-induced? References to Common Turkic // Вестник Санкт-Петербургского университета. Востоковедение и африканистика. 2019. Т. 11. Вып. 2. С. 152-172. https://doi.org/10.21638/spbu13.2019.202 (In English)

Настоящая статья является продолжением исследований в области изучения наклонений глагола и средств выражения модальности в кипрско-турецком языке (КТ). Особое внимание при этом уделено конструкциям, образованным посредством аффиксов волунтатива для 1-го и 3-го лица единственного числа <-(y)AyIm/-sIn> и частицы -(i)di, в дальнейшем < Vol+-(i)di>. В предыдущих исследованиях, посвященных особенностям синтаксиса кипро-турецкого языка, <Vol+-(i)di> описан как заимствованное явление из кипро-греческого языка и, в связи с этим имеет нетюркское происхождение. Эта на сегодняшний день общепризнанная точка зрения в исследованиях по кипро-турецкому языку о нетюркском, заимствованном происхождении <Vol+-(i)di> нуждается в верификации. В связи с этим в данном исследовании, основываясь, во-первых, на работах Старостова, Кононова, во-вторых, на описаниях данной формулы в грамматиках и исследованиях по тюркским языкам, в-третьих, на накопленных фактах, свидетельствующих о наличии данной формулы в тюркских литературных памятниках, т. е. на ранних стадиях развития тюркского языка, и, в-четвертых, привлекая материалы из языков огузской группы, такие как разговорный турецкий, туркменский языки, разработана иная, отличная от предыдущих выводов о ее нетюркском происхождении точка зрения на природу и происхождение данной морфологической парадигмы в КТ в частности и в тюркских языках в целом. Методологической основой исследования и интерпретаций примеров из КТ, собранных во время диалектологических экспедиций, является концепт анализа высказываний по принципу Бондарко "от значения к форме». Настоящая работа не только станет вкладом в изучение грамматических способов выражения категории наклонения и модальности в тюркских языках, но и инициирует продолжение более тщательного изучения межкатегориальных связей в грамматике тюркских языков, опровергая так называемую парадоксальность связи грамматических категорий, в данном случае <волунтативное наклонение +временная копула(?)/ номинальные обломки(?)>.

Ключевые слова: кипрско-турецкий язык, турецкий язык на Кипре, тюркские языки, волунтатив, наклонения глагола в тюркских языках, средства выражения модальности в тюркских языках, копула -idi, туркменский язык, турецкий язык.

Статья поступила в редакцию 23 августа 2018 г., рекомендована к печати 26 марта 2019 г.

Контактная информация:

Сахатова Гюльшен Сахатовна - д-р филол. наук; gulshen.sakhatova@uni-goettingen.de 


\section{Appendix}

\begin{tabular}{ll}
\multicolumn{2}{c}{ Abbreviations } \\
ABL & Ablative \\
ACC & Accusative \\
AOR & Aorist \\
CG & Cypriot Greek \\
CT & Cypriot Turkish \\
des & Desiderative \\
DIR & Directive \\
IMPV & Imperfective \\
IRR & Irrealis \\
LOC & Locative \\
NEG & Negation \\
PAST & Past perfective tense \\
PL & Plural \\
POSS & Possessive \\
PRS & Present tense \\
SG & Singular \\
ST & Standard Turkish \\
VOL & Voluntative \\
VOLdes & Voluntative desiderative \\
VOL/incen & Voluntative incentive \\
VOL/IRR & Voluntative Irrealis \\
VOL/IRRwish & Voluntative Irrealis wish \\
VOL/neces & Voluntative necessity \\
VOL/supp & Voluntative supposition \\
&
\end{tabular}

